\title{
Grouting performance of the Pandan Duri dam shacked by Lombok earthquake 2018
}

\author{
Didi S. Agustawijaya ${ }^{1 *}$, Muji Wahyudi ${ }^{1}$, I Wayan Yasa $^{1}$, Keke F. Ashari ${ }^{1}$, and Ausa R. \\ Agustawijaya $^{2}$ \\ ${ }^{1}$ Department of Civil Engineering, University of Mataram, Mataram 83125, Indonesia \\ ${ }^{2}$ Department of Geomatics Engineering, ITS, Surabaya, Indonesia
}

\begin{abstract}
The Pandan Duri dam has an important role in water supply in the East Lombok District. Unfortunately, Lombok Island is located in a relatively high seismic risk area, as earthquakes occurred in 2018 have ruined almost one third of the island and destroyed thousands of buildings. The Pandan Duri dam is one of many infrastructures shacked by the earthquake. Modelling the dam shows that the grouting installation of the dam has supported the dam after the earthquake. The factor of safety (FoS) of the dam was still 1.76 after the earthquake for the flood water level conditions; but, the displacements could be significant to the stability of the dam, as the dam might displace up to $1.64 \mathrm{~m}$. Although, the current grouting support system might provide the stability to the dam during earthquake events, the dam will certainly require further stability enhancement and close monitoring for possible similar events in the future.
\end{abstract}

\section{Introduction}

The Pandan Duri Dam is located in the East Lombok District of the West Nusa Tenggara Province, Indonesia (Fig. 1), and it has been one of many water infrastructures in Lombok Island [1]. Unfortunately, Lombok Island is a part of the most active seismic area in Indonesia, since three tectonic plates collide one to the others: Eurasia, Indo-Australia and Pacific (Fig. 2).

Earthquake events around the island were generated by two seismic sources: southern subduction mega-thrust and northern back-arc thrust. These two sources fashioned different types of seismic events. The subduction tended to generate deep events; conversely the backarc thrust tended to generate shallow seismic events. Since current earthquakes in 2018 mostly located in the north part of Lombok Island, these seismic events occurred at the backarc basin called the Bali basin, which might cause re-activation of an up-thrusting fault called the Flores fault [2].

Due to current earthquake activity, it is crucial to evaluate the seismicity and calculating peak ground acceleration for Lombok Island, as they could provide high impacts to the island. The consequences of being located within an active seismic area, tectonic forces will

\footnotetext{
* Corresponding author: didiagustawijaya@unram.ac.id
} 
dynamically develop horizontal forces creating instability to any infrastructure and building on the ground.

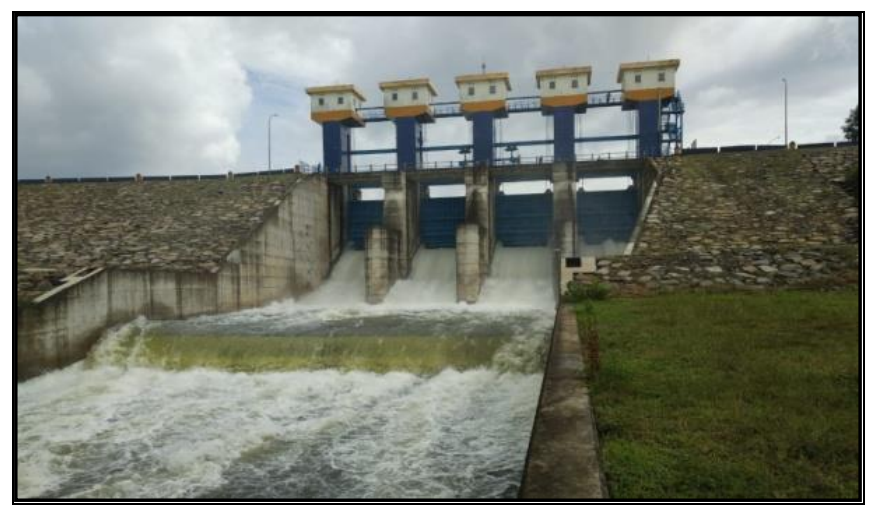

Fig. 1. The Pandan Duri dam located in the East Lombok District of the West Nusa Tenggara Province, Indonesia.

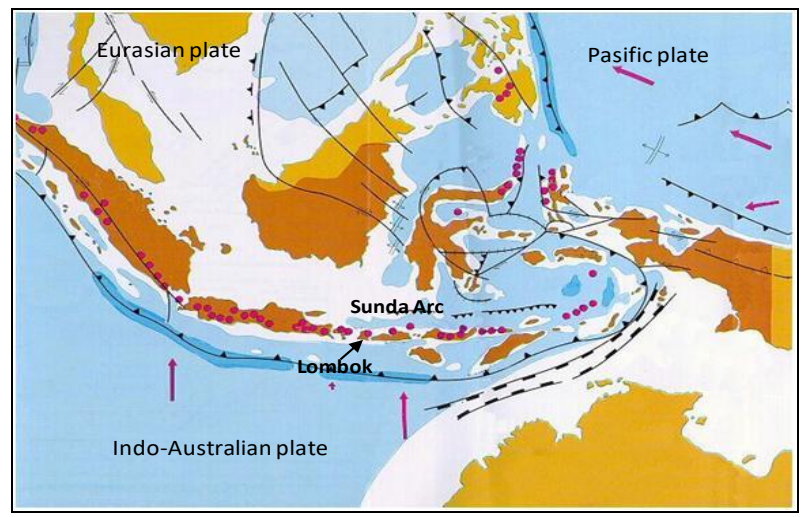

Fig. 2. Tectonic pattern of Indonesia [2, 3].

One of many infrastructures in Lombok Island is the Pandan Duri Dam, where it could face an instability problem after the event. Thus, this paper evaluates the influence of the current earthquake events to the dam by generating re-calculation of earthquake forces using numerical analysis, and foresees the performance of grouting installations to support the dam.

\section{Method}

Earthquake catalogue from the United State geological Survey (USGS) [4] was used to calculate peak ground acceleration (PGA). The Boore-Atkinson empirical equation was then applied for the calculation $[5,6]$. The reason was the empirical equation was suitable to the tectonic condition of Lombok Island, since the current seismic events re-active the reverse fault at the back arc zone of the island. The empirical attenuation relation for shallow faults is, as follows:

$$
\ln Y=F_{M}(M)+F_{D}\left(R_{J B} M\right)+F_{S}\left(V_{S 30}, V_{J B}, M\right)+\varepsilon \sigma \mathrm{T}
$$


where $F_{M}$ is magnitude scaling, $F_{D}$ is distance function, $F_{S}$ is site implication, $\mathrm{M}$ and $\mathrm{R}_{\mathrm{JB}}$ are moment magnitude and the Joyner-Boore distance, respectively.

Then, numerical modelling was conducted to evaluate the grouting performance of the dam. Data available from the project [7] were used in this modelling, including the dam dimension, material properties and hydrological data. Grouting system applied to the dam was according to the standard operation procedures of the Ministry of Public Work [8], and used the SikaGrout 214-11 [9]; then the procedures of earthquake forces calculation followed the SNI PD T-14-2004-A [10].

\section{Results and discussion}

\subsection{Peak ground acceleration and earthquake forces}

The calculations of PGA [5] and earthquake forces [11] can be seen in Table 1. The main shock of the moment magnitude of 6.9 of the $5^{\text {th }}$ August 2018 earthquake event was used for calculation that resulted in a PGA value of 0.6. This PGA might be overvalued for the Pandan Duri dam location [12], which had a hypocentre distance $\mathrm{R}_{\mathrm{JB}}$ of $57 \mathrm{~km}$ located within the intra-arc zone.

Table 1. Parameters for earthquake forces.

\begin{tabular}{|c|c|}
\hline Parameter & Value \\
\hline PGA & 0.6 \\
\hline SDS & 0.9 \\
\hline SD1 & 0.6 \\
\hline FA & 1.0 \\
\hline FV & 1.0 \\
\hline SM $=$ SDS X FA & 0.9 \\
\hline SM1 = SD1 X FV & 0.6 \\
\hline SDS = 2/3 x SMS & 0.6 \\
\hline SD1 = 2/3 x SM1 & 0.4 \\
\hline T0=0.2 x (SD1/SDS) & 0.13 \\
\hline TS = (SD1/SDS) & 0.66 \\
\hline W & $415679.53 \mathrm{~kg} / \mathrm{m} 2$ \\
\hline Ie & 1.25 \\
\hline R & 1.6 \\
\hline V = (SDS x Ie) $/ \mathrm{R} \times$ W & $19.48 \mathrm{~kg} / \mathrm{m} 2$ \\
\hline
\end{tabular}

According to the seismic hazard map [13], the PGA was $0.4 \mathrm{~g}$, which however, is lower than the current calculation (Table 1). Considering the impacts of the event occurred on the $5^{\text {th }}$ August 2018 [14], the PGA of 0.6 seems to be more relevant for current seismic conditions. Then, using data in Table 1, the earthquake force is $\mathrm{V}=19.48 \mathrm{~kg} / \mathrm{cm}^{2}$.

\subsection{Dam design and material properties}

The Pandan Duri dam has dimensions of a length of $950.0 \mathrm{~m}$, a width on the base of 260.92 $\mathrm{m}$, a width on the crest of $10.0 \mathrm{~m}$ (Fig. 3). The foundations area is $110918.73 \mathrm{~m}^{2}$. The elevation of the base is $+230.0 \mathrm{~m}$ above the MSL, and the elevation of the crest is $+284.0 \mathrm{~m}$ above the MSL. The elevation of normal water supply (FSL) is $+264.0 \mathrm{~m}$ above the MSL 


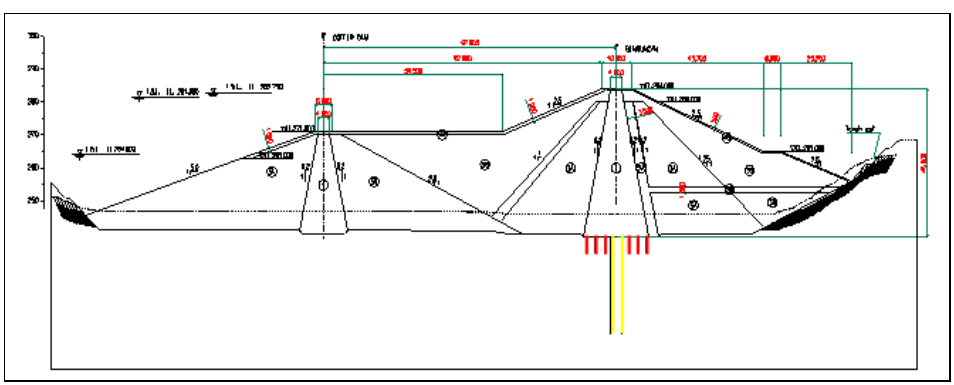

Fig. 3. The Pandan Duri dam lay out [7].

The dam foundations were made of volcanic breccias of the Kalibabak Formation inclined of $8^{0}$ toward the south-east direction [15]. The rock material had a friction angle of $30^{\circ}$ and cohesion of $0.4 \mathrm{~kg} / \mathrm{cm}^{2}[17,17]$.

The dam was supported by a grouting support system in a hexagonal pattern (Fig. 4). The main purpose of grouting is to reduce permeability, but it could also increases shear strength, reduces compressibility, and reduces internal erosion on foundations. The installations might add shear strength to the base of $15 \mathrm{~kg} / \mathrm{cm}^{2}$, so these were also intended to increase the stability of the dam shacked by earthquakes. Since the tectonic instability might be very much possibly to occur in Lombok Island $[19,19]$.

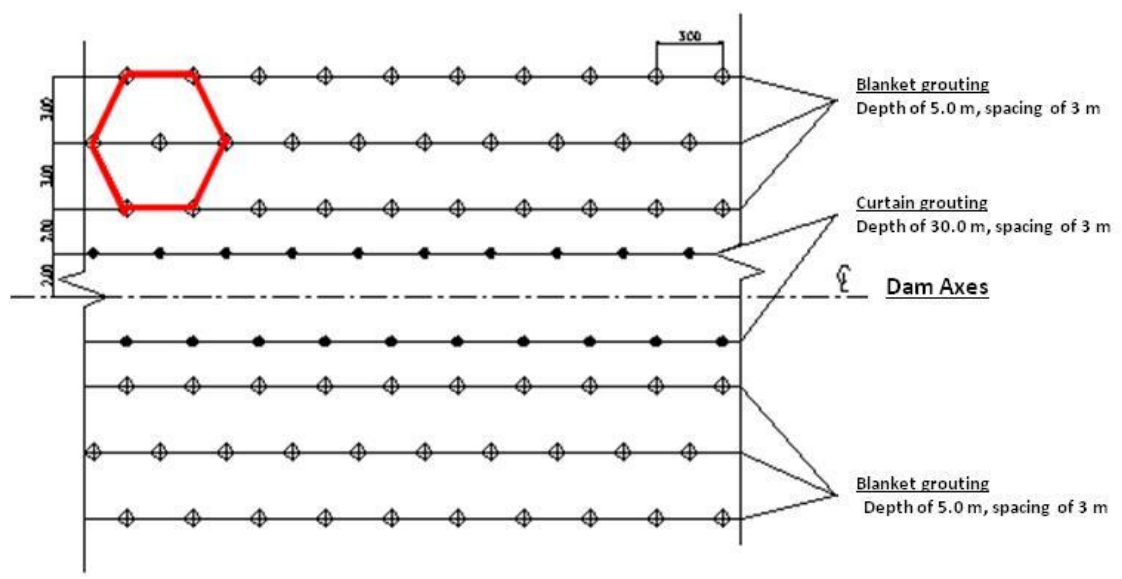

Fig. 4. Grouting installation of trapezoidal pattern [7].

When water filled the reservoir, it had an elevation of $+281.5 \mathrm{~m}$ at a normal water supply level (FSL). The volume of reservoir was $27.2 \times 106 \mathrm{~m}^{3}$. Putting all those data into load calculations, shear forces on the dam base was $415679.5 \mathrm{~kg} / \mathrm{m}^{2}$. The FoS of the dam before earthquake events was 4.96 according to the SNI-1726-2012 [11]. With this value, the dam was considered to stand for earthquake forces that might have a PGA of 0.4. However, the current earthquakes had a PGA value of 0.6 as estimated earlier in Table 1, which was over the estimation. Numerical analyses were then conducted to evaluate the stability of the dam supported by grouting installations influenced by the current earthquake forces.

\subsection{Numerical analysis}

For numerical analysis, two extreme conditions of water levels were applied: low water level (LWL) and flood water level (FWL); under and without the influence of earthquake forces. Material properties in Table 2 were adopted as input parameters in calculations. 
Table 2. Soil material properties of the Pandan Duri dam.

\begin{tabular}{|c|c|c|c|c|c|}
\hline Parameter & Zone 1 & Zone 2 & Zone 3 & Zone 4 & Zone 5 \\
\hline Dry unit weight, $\square$ dry, kN/m3 & 12.99 & 17.66 & 15.54 & 17.0 & 22.0 \\
\hline $\begin{array}{c}\text { Saturated unit weight, } \square \text { sat, } \\
\mathrm{kN} / \mathrm{m} 3\end{array}$ & 17.71 & 20.57 & 19.30 & 20.59 & 24.0 \\
\hline $\begin{array}{c}\text { Permeability, kx, m/sec } \\
\text { Permeability, ky, m/sec }\end{array}$ & $\begin{array}{c}1.375 \times 10- \\
8\end{array}$ & $2.11 \times 10 \times 10-4$ & $8.7 \times 10-9$ & $5.05 \times 10-3$ & $4.22 \times 10-5$ \\
\hline Young's modulus, E, kN/m2 & 11000 & 13000 & 13000 & 15000 & 197000 \\
\hline Poisson's ratio, $\square$ & 0.2 & 0.4 & 0.2 & 0.2 & 0.36 \\
\hline Cohesion, c, kN/m2 & 24.42 & 0 & 23.53 & 0 & 63.20 \\
\hline Friction, $\square, \mathrm{deg}$ & 18 & 30 & 25 & 40 & 45 \\
\hline Dilation, $\square, \mathrm{deg}$ & 0 & 0 & 0 & 0 & 0 \\
\hline
\end{tabular}

\subsubsection{The $L W L$}

The elevation of the LWL was $+264.0 \mathrm{~m}$ above the mean sea level (MSL), or $34 \mathrm{~m}$ above the dam base, while all dimensions of the dam were as stated earlier in the dam design. Numerical analysis shows that the FoS reduced significantly after earthquakes (Fig. 5), although the index was still 1.77, which was still in the range of stable conditions over 1.5.

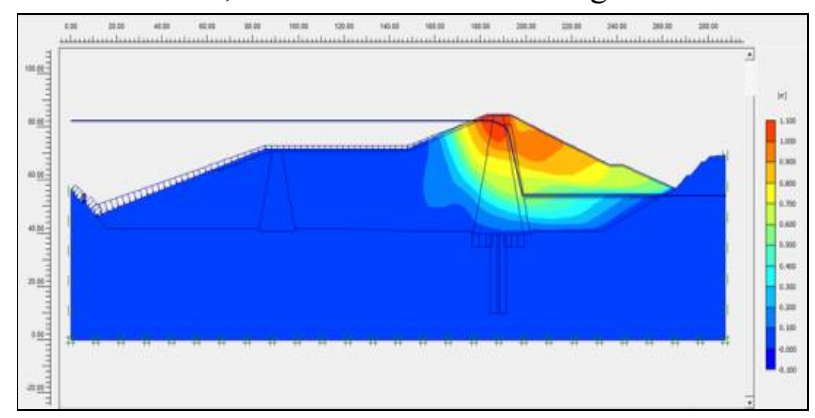

Fig. 5. The LWL model after earthquake events.

However, the displacement could play an important role in the stability of the dam. The numerical analysis shows that the displacements of $8.9 \mathrm{~cm}$ might occur after the earthquake events. This displacement should be fine for the stability of the dam.

\subsubsection{The FWL}

The elevation of flood water level (FWL) was $+282.75 \mathrm{~m}$ above the MSL, or $1.25 \mathrm{~m}$ below the crest of the dam. The FWL model after the earthquake events shows that the FoS slightly reduced from the LWL conditions to be 1.76 (Fig. 6). But, the displacements could be significant, in which the dam could displace down to $164 \mathrm{~cm}$ after the event. This could be significant for the stability of the dam. 


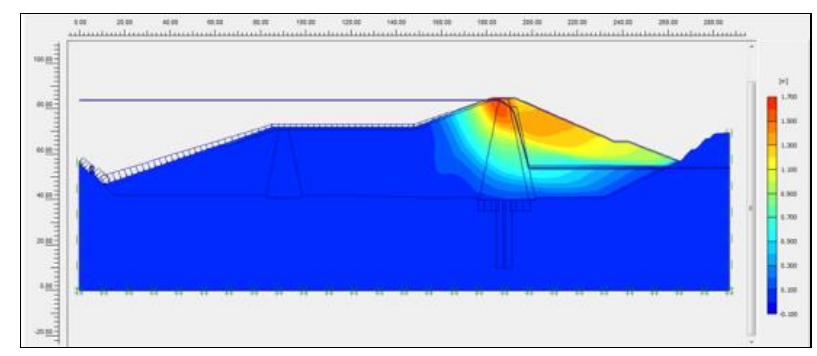

Fig. 6. The FLW model after earthquake events.

From the SF analysis, it can be seen that the SF value was greater than 1.5 , which indicated that the dam was still safe influenced by earthquake forces. The grouting support system might be effective as a reinforcement and addition of resisting forces. When earthquakes occurred, of course, dynamic loads propagate through the dam foundation, then affected the dam slopes. As consequences, an increase in driving forces was followed by a decrease in the factor of safety of the dam. Grouting would, therefore, play a part in the stabilization of the dam.

Water added additional loads to dam, so it changed in the FoS values. The FoS value increased according to the water level, the higher the water level, the lower FoS. Also, an increase in water volume within the reservoir would increase pore water pressures working on the foundations of the dam. This could result in decreasing the shear strength of the foundation.

\section{Conclusions}

Based on numerical analysis, the grouting installations of the Pandan Duri dam was able to stand earthquake forces after the event in 2018. The factor of safety was still over 1.5; although, flood might worsen the stability of the dam, since the FWL conditions tended to have a lower stability index than that of the LWL. Displacements could be significant in the stability of the dam as these could reach $1.64 \mathrm{~m}$ after the event. Stability enforcements are certainly required to strengthen the dam for future similar events that may possibly provide worse stability problems.

\section{Acknowledgement}

Authors acknowledge supports provided by Balai Wilayah Sungai Nusa Tenggara I, Mataram.

\section{References}

1. S.M. Noviyanthi, D.S. Agustawijaya, S. Murtiadi, Int. J. Civ. Eng. Tech, 9, 1, 238244, (2018)

2. W. Hamilton, Earthquake Map of Indonesian Region, USGS, Misc. Invest. Serial Map 1-875-C, (1974)

3. H. Rachmat, M. Rosana, A. Wirakusumah, G. Jabbar, Ind. J. Geosci., 3, 2, 107-126 (2016)

4. United State Geological Survey (USGS), (2018), (accessed 30th Sept. 2018)

5. D.M. Boore, G.M. Attkinson, Earthq. Spec., 24, 1, 99-138 (2008) 
6. J. Douglas, Ground motion prediction equations 1964-2017, Dept. Civ. Env. Eng., Univ. Strathclyde, Glasgow, UK (2017)

7. Balai Wilayah Sungai Nusa Tenggara Barat, Dokumen Perencanaan Bendungan Pandan Duri, (2012) (in Indonesian)

8. The Indonesia Ministry of Public Work, SNI T-01-2002 (2002) (in Indonesian)

9. SikaGrout 214-11: https://www.google.com/search?client=firefox-b$\mathrm{d} \& \mathrm{q}=8 . \% 09$ SikaGrout $+214-11$

10. Indonesian National Standards, SNI PD T-14-2004-A (2004) (in Indonesian)

11. Indonesian National Standards, SNI-1726-2012 (2012) (in Indonesian)

12. F. Afrizal, D.S. Agustawijaya, A. Lestari, IOP Conf. Series: Earth Env. Sci. 413, 012010 (2020)

13. Indonesia Ministry of Public Work, Peta Sumber dan Bahaya Gempa Indonesia Tahun 2017, M. Irsyam, et al. (Editors) (2018) (in Indonesian)

14. D.S. Agustawijaya, T. Sulistyowati, B.A. Layli, A.R. Agustawijaya, IOP Conf. Series: Earth Env. Sci. 389, 012051 (2019)

15. S. Mangga, S. Atmawinata, B. Hermanto, B. Setyogroho, Geological Map of The Lombok Sheet, West Nusa Tenggara, Geol. Res. Dev. Centre, Bandung (1994)

16. D.S. Agustawijaya, Ind. J. Geosci. 5, 2, 93-205 (2018)

17. D.S. Agustawijaya, Int. J. Tech., 10, 1, 16-26 (2019)

18. D.S. Agustawijaya, H. Sulistiyono, I. Elhuda, MATEC Web Conf., 195 (03018) (2018)

19. B. Sunardi, M. Istikomah, Sulastri, J. Riset Geof. Ind., 1, 1, 23-28 (2017) (in Indonesian) 